\title{
Physico-chemical properties and mineral content of selected tropical fruits in Bangladesh
}

\author{
R. Ara ${ }^{1,2}$, S. Jahan ${ }^{3}$, A. T. M. Abdullah ${ }^{3}$, A. N. M. Fakhruddin ${ }^{1}$ and B. K. Saha ${ }^{3}$ * \\ ${ }^{1}$ Department of Environmental Sciences, Jahangirnagar University, Savar, Dhaka-1342, Bangladesh. \\ ${ }^{2}$ Department of Food Engineering and Tea Technology, Shahjalal University of Science and Technology, Sylhet \\ -3114, Bangladesh. \\ ${ }^{3}$ Institute of Food Science \& Technology, Bangladesh Council of Scientific and Industrial Research, Dhanmondi, \\ Dhaka-1205, Bangladesh.
}

\begin{abstract}
Physico-chemical properties and mineral contents of tropical fruits available at local market in Dhaka city were evaluated as fruits are the essential part of human diet to supply required micronutrient. Among the analyzed fruits, maximum and minimum amount of moisture was found in java apple $(93.26 \pm 1.77 \%)$ and indian plum $(66.86 \pm 1.81 \%)$ respectively. Mango contains highest amount of total soluble solids $(15.20 \pm 0.81 \%)$ and total sugar $(4.71 \pm 0.08 \%)$. Highest and lowest amount of vitamin $\mathrm{C}$ was found in guava $(212.82 \pm 6.92 \mathrm{mg} / 100 \mathrm{~g})$ and java apple $(10 \pm 1.77 \mathrm{mg} / 100 \mathrm{~g})$ respectively. Approximate energy value was found highest in indian plum $(128.1 \pm 5.51 \mathrm{kcal} / 100 \mathrm{~g})$ and lowest in green palmyra palm $(27.7 \pm 2.64 \mathrm{kcal} / 100 \mathrm{~g})$. Indian plum $(139.32 \pm 9.53 \mathrm{mg} / 100 \mathrm{~g})$ and mango $(34.03 \pm 6.81 \mathrm{mg} / 100 \mathrm{~g})$ contain highest and lowest amount of sodium whereas rose apple $(75.15 \pm 0.02 \mathrm{mg} / 100 \mathrm{~g})$ and mango $(10.23 \pm 1.94 \mathrm{mg} / 100 \mathrm{~g})$ contain highest and lowest amount of potassium respectively. Heavy metals $(\mathrm{As}, \mathrm{Cd}, \mathrm{Pb}$ and $\mathrm{Hg}$ ) were not detected in analyzed tropical fruits. This study suggests that the tropical fruits are enriched in micronutrients.
\end{abstract}

Keywords: Tropical fruits; Physico-chemical properties; Vitamin C; Mineral content; Heavy metals

\section{Introduction}

The composition of fruits may vary from one continent to another, one country to another in the same continent and in the same country and also may occur region to region due to change of climatic condition and sometimes rainfall (Haque et al., 2009). A large number of tropical fruits and vegetables were grown in Bangladesh have a high nutritional value and play an important role in human nutrition (Rahman et al., 2007) and also enriched in antioxidant, minerals, vitamins and dietary diversification (Jahan et al., 2011). Small amount of micronutrients are needed for good health along with energy. Vitamins are vital in the control of bio-chemical reaction (Carr and Frei, 1999).

Fruit and vegetables are important components of a healthy diet and recent epidemiological studies suggest that regular consumption of adequate amounts could help to prevent major chronic diseases. Fruit and vegetables are important source of natural antioxidants which provide protection against various types of diseases and other health benefits (Shui and Leong, 2006). Increased consumption of fruit and vegetables significantly reduce the incidence of chronic diseases, such as cancer, cardiovascular diseases and other aging-related pathologies (Prakash et al., 2012).

There are some food composition tables available in Bangladesh which does not include all tropical fruits as well as limited to data in aspect of physico-chemical properties, minerals and heavy metal content, which is essential for national nutritional planning as well as nutritionist, dietician and consumers. The present study has conducted to address of physico-chemical properties, minerals and heavy metal contents in selected tropical fruits (e.g. guava, pomelo, karanda, mango, java apple, rose apple, indian plum, green palmyra palm and jujube) of Bangladesh collected from different local market of Dhaka city, those the people of Bangladesh usually take in their daily life. Findings from this study may provide information for national food composition table in some extent.

\section{Materials and Methods}

Experiments were carried out in Fruit Technology Research Section at Institute of Food Science \& Technology (IFST),

*Corresponding author: E-mail: bksbcsir@yahoo.com 
Bangladesh Council of Scientific and Industrial Research (BCSIR), Dhaka. The same fruit samples were collected from three different local markets in Dhaka city. Collected samples were fresh, matured, well shaped and free from insect's bites and other organoleptic deterioration. The freshly collected sample was washed with de-ionized water to eliminate visible dirt and removed the water quickly with a blotting paper. Then the samples were cut into small pieces, homogenized and accurate amount was weighed as required for different analysis. The samples were analyzed for three replication.

The edible portion of whole fruit was determined by subtracting the weight of inedible parts of fruits from the weight of whole fruits. The $\mathrm{p}^{\mathrm{H}}$ of fruit extract was determined with a digital pH meter (Type H1 98106 by HANNA) and titratable acidity was estimated with the visual acid base by digital method (Ranganna, 1986). Crude fiber was determined by standard AOAC method (AOAC, 2005). Moisture content was determined by digital moisture analyzer (AnD MX-50). The total soluble solid (TSS) was determined with a hand refractometer (Type ATAGO, Model-9099). Reducing sugar and total sugar were determined by Lane and Eynon method (Ranganna, 1986). The estimation of total protein was made by Kjeldahl method and the total fat content of sample was determined by the standard AOAC method (AOAC, 2005). The content of total carbohydrate was determined by the following equation:

Total Carbohydrate $(\%)=100-\{$ Moisture $(\%)+$ Protein $(\%)$ + Fat $(\%)+$ Ash $(\%)\}$

Vitamin C was estimated by 2, 6-Dichlorophenolindophenol visual titration method according to AOAC (AOAC, 2005). Ash was determined by heating sample at $600^{\circ} \mathrm{C}$ in muffle furnace (Type Gallenkamp, Model-S90 NC/NA) for six hours until a constant weight was reached. Mineral solutions were prepared to analyze minerals and heavy metals (Kirk and Sawyer, 1991). All the minerals and heavy metals were estimated by Flame Atomic Absorption Spectrometric method (Thermo-Scientific iCE 3000 series, Atomic Absorption Spectrometer), and vapor hydride generation system used in case of $\mathrm{As}$ and $\mathrm{Hg}$ analysis. The approximate food energy was estimated (Edeoga et al., 2003), using equation:

$\mathrm{FE}=\{(\% \mathrm{TC}-\% \mathrm{CF}) \times 4\}+(\% \mathrm{TF} \times 9)+(\% \mathrm{TP} \times 4)$

Where, $\mathrm{FE}=$ Food Energy in $\mathrm{Kcal} / 100 \mathrm{~g}, \mathrm{TC}=$ Total Carbohydrate, $\mathrm{CF}=$ Crude Fiber, $\mathrm{TF}=$ Total Fat, $\mathrm{TP}=$ Total Protein.

Table I. Physico-chemical properties of selected tropical fruits (Result expressed as per 100 gm of edible portion)

\begin{tabular}{|c|c|c|c|c|c|c|c|c|c|c|c|c|c|c|}
\hline $\begin{array}{l}\text { Name of } \\
\text { the fruits }\end{array}$ & $\begin{array}{c}\text { Edible } \\
\text { Portion } \\
(\%)\end{array}$ & $\mathrm{p}^{\mathrm{H}}$ & $\begin{array}{c}\text { Moisture } \\
(\%)\end{array}$ & $\begin{array}{l}\text { TSS } \\
(\%)\end{array}$ & $\begin{array}{c}\text { Total Sugar } \\
(\%)\end{array}$ & $\begin{array}{c}\text { Reducing } \\
\text { Sugar } \\
(\%)\end{array}$ & $\begin{array}{c}\text { Titratable } \\
\text { acidity } \\
(\%)\end{array}$ & $\begin{array}{c}\text { Total } \\
\text { Carbohydrate } \\
(\mathrm{gm})\end{array}$ & $\begin{array}{l}\text { Total } \\
\text { Protein } \\
(\mathrm{gm})\end{array}$ & $\begin{array}{l}\text { Total Fat } \\
(\mathrm{gm})\end{array}$ & $\begin{array}{l}\text { Ash } \\
(\mathrm{gm})\end{array}$ & $\begin{array}{l}\text { Crude Fiber } \\
\text { (gm) }\end{array}$ & $\begin{array}{l}\text { Total Energy } \\
\text { (Kcal) }\end{array}$ & $\begin{array}{c}\text { Vitamin } \mathrm{C} \\
(\mathrm{mg})\end{array}$ \\
\hline $\begin{array}{l}\text { Guava } \\
\text { (Psidium } \\
\text { guajava) }\end{array}$ & $99.78 \pm 0.05$ & $4.20 \pm 0.05$ & $85.30 \pm 2.28$ & $5.35 \pm 0.31$ & $3.69 \pm 0.31$ & $2.16 \pm 0.15$ & $0.38 \pm 0.04$ & $12.06 \pm 2.04$ & $1.59 \pm 0.14$ & $0.48 \pm 0.04$ & $0.57 \pm 0.06$ & $3.21 \pm 0.18$ & $46.08 \pm 2.23$ & $212.82 \pm 6.92$ \\
\hline $\begin{array}{l}\text { Pomelo } \\
\text { (Citrus } \\
\text { maxima) }\end{array}$ & $51.14 \pm 2.39$ & $4.22 \pm 0.03$ & $84.67 \pm 1.82$ & $7.30 \pm 0.08$ & $4.14 \pm 0.06$ & $3.57 \pm 0.13$ & $0.76 \pm 0.06$ & $14.15 \pm 1.35$ & $0.54 \pm 0.03$ & $0.39 \pm 0.02$ & $0.25 \pm 0.05$ & $0.35 \pm 0.04$ & $60.87 \pm 5.00$ & $160.98 \pm 5.88$ \\
\hline $\begin{array}{l}\text { Rose Apple } \\
\text { (Syzygium } \\
\text { jambos) }\end{array}$ & $75.86 \pm 3.28$ & $5.40 \pm 0.02$ & $87.32 \pm 1.70$ & $6.78 \pm 0.24$ & $3.90 \pm 0.14$ & $3.11 \pm 0.07$ & $0.25 \pm 0.04$ & $11.78 \pm 1.39$ & $0.07 \pm 0.01$ & $0.36 \pm 0.04$ & $0.47 \pm 0.02$ & $1.01 \pm 0.08$ & $46.6 \pm 2.84$ & $25.00 \pm 2.95$ \\
\hline $\begin{array}{l}\text { Indian Plum } \\
\text { (Flacourtia } \\
\text { jangomas) }\end{array}$ & $84.13 \pm 2.70$ & $3.64 \pm 0.01$ & $66.86 \pm 1.81$ & $6.52 \pm 0.17$ & $4.16 \pm 0.28$ & $3.24 \pm 0.17$ & $0.51 \pm 0.09$ & $31.31 \pm 3.64$ & $0.69 \pm 0.05$ & $0.42 \pm 0.03$ & $0.72 \pm 0.02$ & $0.92 \pm 0.10$ & $128.1 \pm 5.51$ & $75.00 \pm 4.15$ \\
\hline $\begin{array}{l}\text { Karanda } \\
\text { (Carissa } \\
\text { carandas) }\end{array}$ & $85.07 \pm 2.57$ & $3.11 \pm 0.01$ & $83.51 \pm 1.29$ & $5.20 \pm 0.06$ & $1.79 \pm 0.09$ & $0.45 \pm 0.05$ & $1.28 \pm 0.08$ & $15.16 \pm 2.06$ & $0.88 \pm 0.04$ & $0.11 \pm 0.03$ & $0.34 \pm 0.03$ & $0.95 \pm 0.11$ & $61.35 \pm 2.53$ & $25.00 \pm 2.82$ \\
\hline $\begin{array}{c}\text { Green } \\
\text { Palmyra } \\
\text { palm } \\
\text { (Borassus } \\
\text { flabellifer) }\end{array}$ & $21.06 \pm 1.70$ & $5.67 \pm 0.01$ & $91.60 \pm 1.45$ & $6.65 \pm 0.10$ & $4.09 \pm 0.07$ & $3.29 \pm 0.09$ & $0.12 \pm 0.02$ & $7.71 \pm 0.08$ & $0.24 \pm 0.05$ & $0.10 \pm 0.02$ & $0.35 \pm 0.06$ & $1.25 \pm 0.07$ & $27.7 \pm 2.64$ & $17.50 \pm 2.52$ \\
\hline $\begin{array}{c}\text { Mango } \\
\text { (Mangifera } \\
\text { indica) }\end{array}$ & $61.28 \pm 2.15$ & $4.03 \pm 0.02$ & $85.75 \pm 1.24$ & $15.20 \pm 0.81$ & $4.71 \pm 0.08$ & $3.99 \pm 0.13$ & $0.28 \pm 0.02$ & $12.83 \pm 1.83$ & $1.11 \pm 0.08$ & $0.14 \pm 0.02$ & $0.17 \pm 0.04$ & $2.72 \pm 0.09$ & $46.14 \pm 3.55$ & $45.00 \pm 5.71$ \\
\hline $\begin{array}{c}\text { Java Apple } \\
\text { (Syzygium } \\
\text { samarangense) }\end{array}$ & $95.43 \pm 1.62$ & $4.65 \pm 0.01$ & $93.26 \pm 1.77$ & $4.78 \pm 0.20$ & $3.07 \pm 0.10$ & $2.35 \pm 0.09$ & $0.44 \pm 0.04$ & $4.91 \pm 0.20$ & $0.51 \pm 0.13$ & $1.16 \pm 0.09$ & $0.16 \pm 0.03$ & $0.86 \pm 0.10$ & $28.68 \pm 5.90$ & $10.00 \pm 1.77$ \\
\hline $\begin{array}{c}\text { Jujube } \\
\text { (Zizyphus } \\
\text { mauritiana) }\end{array}$ & $85.89 \pm 1.68$ & $3.58 \pm 0.02$ & $84.09 \pm 1.21$ & $4.78 \pm 0.07$ & $0.96 \pm 0.13$ & $0.67 \pm 0.05$ & $1.28 \pm 0.07$ & $12.99 \pm 2.32$ & $1.39 \pm 0.09$ & $1.00 \pm 0.16$ & $0.53 \pm 0.10$ & $2.08 \pm 0.23$ & $58.2 \pm 5.55$ & $113.00 \pm 7.70$ \\
\hline
\end{tabular}


Dietary fiber was not analyzed and not considered in the calculation of total energy though fruits contain fair amount of dietary fiber among crude fiber and that's why in this case food energy may be termed as approximate food energy.

\section{Results and Discussion}

In Table I, edible portion, $\mathrm{p}^{\mathrm{H}}$, moisture, TSS, total sugar, reducing sugar, titratable acidity, total carbohydrate, total protein, total fat, ash, crude fiber, total energy and vitamin $\mathrm{C}$ values are given. The highest amount of edible portion was observed in guava $(99.78 \pm 0.05 \%)$. Edible portion of guava may be $100 \%$ because many people consume the whole portion (pericarp and seed) of guava. Among the selected fruits, the lowest amount of edible portion was found in green Palmyra palm $(21.06 \pm 1.70 \%)$. The value is logical due to thick skin of green Palmyra palm.
The $\mathrm{p}^{\mathrm{H}}$ value among the tropical fruits was found to vary $(3.11 \pm 0.01 \%$ to $5.67 \pm 0.01 \%)$. The highest amount of $\mathrm{p}^{\mathrm{H}}$ and the lowest amount of titratable acidity was observed in green palmyra palm $(5.67 \pm 0.01 \%)$ and $(0.12 \pm 0.02 \%)$ respectively. The lowest amount of $\mathrm{P}^{\mathrm{H}}$ was observed in karanda $(3.11 \pm 0.01 \%)$ and the highest value of titratable acidity was found almost same for karanda and jujube $(1.28 \pm 0.08 \%)$. The moisture content of the selected fruits ranged between $66.86 \pm 1.81 \%$ and $93.26 \pm 1.77 \%$. Among the analyzed fruits, java apple contains the highest amount of moisture $(93.26 \pm 1.77 \%)$ and the lowest amount of moisture $(66.86 \pm 1.81 \%)$ was found in indian plum. It was reported that, moisture content of different tropical fruits varied from 79.1 to $86.1 \%$ (Gopalan et al., 1993).

The total soluble solid (TSS) among the selected fruits ranges from $4.78 \pm 0.20 \%$ to $15.20 \pm 0.81 \%$. The highest amount of

Table II. Mineral contents of selected tropical fruits (Result expressed as per $100 \mathrm{gm}$ of edible portion)

\begin{tabular}{|c|c|c|c|c|c|c|c|c|c|}
\hline $\begin{array}{l}\text { Name of the } \\
\text { fruits }\end{array}$ & $\begin{array}{l}\text { Copper } \\
(\mathrm{mg})\end{array}$ & $\begin{array}{l}\text { Iron } \\
(\mathrm{mg})\end{array}$ & $\begin{array}{l}\text { Zinc } \\
(\mathrm{mg})\end{array}$ & $\begin{array}{c}\text { Manganese } \\
(\mathrm{mg})\end{array}$ & $\begin{array}{l}\text { Sodium } \\
\text { (mg) }\end{array}$ & $\begin{array}{c}\text { Potassium } \\
\text { (mg) }\end{array}$ & $\begin{array}{l}\text { Calcium } \\
\text { (mg) }\end{array}$ & $\begin{array}{l}\text { Magnesium } \\
(\mathrm{mg})\end{array}$ & $\begin{array}{c}\text { Aluminium } \\
\text { (mg) }\end{array}$ \\
\hline $\begin{array}{c}\text { Guava } \\
\text { (Psidium } \\
\text { guajava) }\end{array}$ & $21.30 \pm 3.12$ & ND & $2.47 \pm 0.46$ & ND & $68.78 \pm 11.24$ & $15.65 \pm 3.07$ & $27.13 \pm 4.42$ & $2.75 \pm 0.29$ & ND \\
\hline $\begin{array}{l}\text { Pomelo } \\
\text { (Citrus } \\
\text { maxima) }\end{array}$ & $0.02 \pm 0.03$ & ND & ND & ND & $58.72 \pm 3.13$ & $13.71 \pm 4.05$ & $28.46 \pm 4.02$ & $1.07 \pm 0.13$ & $0.50 \pm 0.23$ \\
\hline $\begin{array}{c}\text { Rose Apple } \\
\text { (Syzygium } \\
\text { jambos) }\end{array}$ & $12.82 \pm 3.83$ & ND & ND & ND & $91.36 \pm 3.28$ & $75.15 \pm 0.02$ & $34.56 \pm 1.70$ & $5.98 \pm 0.24$ & $1.05 \pm 0.14$ \\
\hline $\begin{array}{l}\text { Indian Plum } \\
\text { (Flacourtia } \\
\text { jangomas) }\end{array}$ & ND & ND & ND & $2.85 \pm 0.26$ & $139.32 \pm 9.53$ & $56.19 \pm 7.42$ & $79.41 \pm 4.96$ & $28.62 \pm 5.46$ & $0.69 \pm 0.07$ \\
\hline $\begin{array}{c}\text { Karanda } \\
\text { (Carissa } \\
\text { carandas) }\end{array}$ & ND & ND & ND & ND & $38.04 \pm 6.75$ & $23.61 \pm 1.98$ & $28.89 \pm 3.68$ & $1.86 \pm 0.36$ & $0.60 \pm 0.06$ \\
\hline $\begin{array}{c}\text { Green Palmyra } \\
\text { palm (Borassus } \\
\text { flabellifer) }\end{array}$ & ND & ND & ND & ND & $56.74 \pm 6.52$ & $41.20 \pm 6.85$ & $23.15 \pm 3.76$ & $7.32 \pm 0.26$ & $0.25 \pm 0.05$ \\
\hline $\begin{array}{c}\text { Mango } \\
\text { (Mangifera } \\
\text { indica) }\end{array}$ & $\mathrm{ND}$ & ND & ND & $6.16 \pm 1.19$ & $34.03 \pm 6.81$ & $10.23 \pm 1.94$ & $19.45 \pm 5.27$ & $1.54 \pm 0.51$ & $0.22 \pm 0.10$ \\
\hline $\begin{array}{c}\text { Java Apple } \\
\text { (Syzygium } \\
\text { samarangense) }\end{array}$ & $6.86 \pm 1.82$ & ND & $17.2 \pm 4.50$ & $32.64 \pm 5.08$ & $60.73 \pm 4.92$ & $23.78 \pm 3.45$ & $43.01 \pm 2.26$ & $0.77 \pm 0.08$ & ND \\
\hline $\begin{array}{c}\text { Jujube } \\
\text { (Zizyphus } \\
\text { mauritiana) }\end{array}$ & ND & ND & ND & ND & $49.53 \pm 5.05$ & $68.19 \pm 12.06$ & $36.31 \pm 8.02$ & $19.66 \pm 1.90$ & ND \\
\hline
\end{tabular}


TSS was found in mango $(15.20 \pm 0.81 \%)$ and the lowest amount of TSS was found in java apple and jujube $(4.78 \pm 0.20 \%)$. Generally, TSS indicates more sugar in the pulp. The more ripe the fruits the more amount of sugar in fruits (Haque et al., 2009). The sugar content of fresh fruits ranges between $2 \%$ and $30 \%$ (Norman, 1976). This range is as similar to our present study. Mango contains the highest amount of total sugar $(4.71 \pm 0.08 \%)$ and reducing sugar $(3.99 \pm 0.13 \%)$. The lowest amount of reducing sugar was found in karanda $(0.45 \pm 0.05 \%)$ and the lowest amount total sugar was found in jujube $(0.96 \pm 0.13 \%)$. In this study, it was found that protein content of different tropical fruits ranges between $0.07 \pm 0.01 \%$ and $1.59 \pm 0.14 \%$. The highest amount of protein was found in guava $(1.59 \pm 0.14 \%)$ and the lowest amount of protein was found in rose apple $(0.07 \pm 0.01 \%)$. It was reported that in fruits, maximum protein content ranges $1.57 \%$ to $5.42 \%$ but in the different varieties tropical fruits it varies from 0.4 to $0.8 \%$ (Gopalan et al., 1993). Usually fat content of different fruits is not greater than $1 \%$ (Norman, 1976). In our study, it was found that the fat content of different fruit ranges between $0.10 \pm 0.02 \%$ and $1.16 \pm 0.09 \%$. The highest amount of fat was found in java apple $(1.16 \pm 0.09 \%)$ and the lowest amount of fat was found in green palmyra palm $(0.10 \pm 0.02 \%)$. The total amount of ash (minerals) present in selected fruits ranges between $0.16 \pm 0.03 \%$ and $0.72 \pm 0.02 \%$. Maximum content of ash was found in indian plum $(0.72 \pm 0.02 \%)$ and minimum content of ash was found in java apple $(0.16 \pm 0.03 \%)$.
Maximum content of crude fiber was found in guava $(3.21 \pm 0.18 \%)$ and minimum content of crude fiber was found in pomelo $(0.35 \pm 0.04 \%)$. In this study, total carbohydrate present in fruits ranges between $4.91 \pm 0.20 \%$ and $31.31 \pm 3.64 \%$. The highest amount of carbohydrate was present in indian plum $(31.31 \pm 3.64 \%)$ and the lowest amount of carbohydrate was found in java apple $(4.91 \pm 0.20 \%)$. Fruits, rich in carbohydrates provide high amount of energy. Indian plum show the highest amount of approximate food energy $(128.1 \pm 5.51 \mathrm{kcal} / 100 \mathrm{~g})$ due to its high carbohydrate content and the green palmyra palm shows the lowest amount of approximate food energy $(27.7 \pm 2.64 \mathrm{kcal} / 100 \mathrm{~g})$. In present study we observed that, guava contain highest amount of vitamin C $(212.82 \pm 6.92 \mathrm{mg} / 100 \mathrm{~g})$ and java apple contain lowest amount of vitamin C $(10 \pm 1.77 \mathrm{mg} / 100 \mathrm{~g})$. Nutrient database showed the range of vitamin $\mathrm{C}$ in the tropical fruits from 9.01 to $210.47 \mathrm{mg} / 100 \mathrm{~g}$ (USDA, 2010) which has been analyzed by using HPLC method whereas the information revealed from this study on vitamin $\mathrm{C}$ has been estimated by 2, 6-Dichlorophenolindophenol visual titration method according to AOAC instead of HPLC method. The North American Dietary Reference, recommended daily intake of vitamin C $90 \mathrm{mg}$ and not more than $2 \mathrm{gm}$ (USDA, 2010) and whereas in case of adult (19-65 years) population group recommended nutrient intake (RNI) for vitamin $\mathrm{C}$ is $45 \mathrm{mg} /$ day $(\mathrm{WHO} / \mathrm{FAO}, 2002)$.

In Table II, the minerals content are depicted. The anti-oxidant minerals those are found in selected fruit

Table III. Toxic heavy metal contents of selected tropical fruits (Result expressed as per $100 \mathrm{~g}$ of edible portion)

\begin{tabular}{ccccc}
\hline Name of the fruits & Arsenic $(\mu \mathrm{g})$ & Cadmium $(\mathrm{mg})$ & Lead(mg) & Mercury $(\mu \mathrm{g})$ \\
\hline Guava (Psidium guajava) & ND & ND & ND & ND \\
Pomelo (Citrus maxima) & ND & ND & ND & ND \\
Rose Apple (Syzygium jambos) & ND & ND & ND & ND \\
Indian Plum (Flacourtia jangomas) & ND & ND & ND & ND \\
Karanda (Carissa carandas) & ND & ND & ND & ND \\
Green Palmyra palm (Borassus flabellifer) & ND & ND & ND & ND \\
Mango (Mangifera indica) & ND & ND & ND & ND \\
JavaApple (Syzygium samarangense) & ND & ND & ND & ND \\
Jujube (Zizyphus mauritiana) & ND & ND & ND & ND \\
\hline
\end{tabular}


samples are copper, manganese and zinc. These minerals are called micro-minerals. Copper was found in guava, rose apple, pomelo and java apple $21.30 \pm 3.12 \mathrm{mg} / 100 \mathrm{~g}$, $12.82 \pm 3.83 \mathrm{mg} / 100 \mathrm{~g}, \quad 0.02 \pm 0.03 \mathrm{mg} / 100 \mathrm{~g} \quad$ and $6.86 \pm 1.82 \mathrm{mg} / 100 \mathrm{~g}$ respectively. Iron content was not detected in analyzed fruits. Among the analyzed fruits, zinc was found in guava and java apple, $2.47 \pm 0.46 \mathrm{mg} / 100 \mathrm{~g}$ and $17.20 \pm 4.50 \mathrm{mg} / 100 \mathrm{~g}$ respectively. Manganese content of the selected fruits was found in indian plum, mango and java apple, $\quad 2.85 \pm 0.26 \mathrm{mg} / 100 \mathrm{~g}, \quad 6.16 \pm 1.19 \mathrm{mg} / 100 \mathrm{~g} \quad$ and $32.64 \pm 5.08 \mathrm{mg} / 100 \mathrm{~g}$ respectively.

It was observed that sodium presents in different fruits ranges between $139.32 \pm 9.53 \mathrm{mg} / 100 \mathrm{~g}$ and $34.03 \pm 6.81 \mathrm{mg} / 100 \mathrm{~g}$. The highest amount of sodium was found in indian plum $(139.32 \pm 9.53 \mathrm{mg} / 100 \mathrm{~g})$ and lowest amount of sodium was found in mango $(34.03 \pm 6.81 \mathrm{mg} / 100 \mathrm{~g})$. In analyzed fruits, potassium present in different fruits ranges between $75.15 \pm 0.02 \mathrm{mg} / 100 \mathrm{~g}$ and $10.23 \pm 1.94 \mathrm{mg} / 100 \mathrm{~g}$. The highest amount of potassium was found in rose apple $(75.15 \pm 0.02 \mathrm{mg} / 100 \mathrm{~g})$ and lowest amount of potassium $(10.23 \pm 1.94 \mathrm{mg} / 100 \mathrm{~g})$ was found in mango. Potassium content of tropical fruits varies from 45 to $450 \mathrm{mg} / 100 \mathrm{~g}$ (Gopalan et al., 1993). Calcium amount in this study was found between $79.41 \pm 4.96 \mathrm{mg} / 100 \mathrm{~g}$ and $19.45 \pm 5.27 \mathrm{mg} / 100 \mathrm{~g}$. It was reported that calcium content of tropical fruits varies from 4-50mg/100g (Gopalan et al., 1993). Among the fruits analyzed, the highest amount of magnesium was found in indian plum $(28.62 \pm 5.46 \mathrm{mg} / 100 \mathrm{~g})$ and lowest amount was found in java apple $(0.77 \pm 0.08 \mathrm{mg} / 100 \mathrm{~g})$. Among the analyzed fruits, aluminium content ranges from $1.05 \pm 0.14 \mathrm{mg} / 100 \mathrm{~g}$ and $0.22 \pm 0.10 \mathrm{mg} / 100 \mathrm{~g}$. The highest amount of aluminium present in rose apple $(1.05 \pm 0.14 \mathrm{mg} / 100 \mathrm{~g})$ and lowest amount was found in mango $(0.22 \pm 0.10 \mathrm{mg} / 100 \mathrm{~g})$.

Toxic heavy metals namely arsenic, cadmium, lead and mercury were studied. In Table III, values of toxic heavy metals are given. These heavy metals are harmful and become toxic for health if they are taken above the permissible limit. Among the fruits analyzed arsenic, cadmium, lead and mercury were not detected. So the consumption of analyzed fruits are safe from heavy metal contamination.

\section{Conclusion}

Present study indicates that tropical fruits of Bangladesh are affluent sources of fiber, vitamin $\mathrm{C}$ and as well as many important minerals. The analyzed fruits contain adequate amount of fiber, a small amount of protein and fat. They also rich in sodium, potassium, calcium and magnesium and a little amount of zinc, manganese. Indian plum contains highest amount of energy and also sodium, calcium and magnesium. Rose apple contains highest amount of potassium. Java apple contains the highest amount of zinc. The heavy metals were not detected among the analyzed fruits, for this reason they are safe for consumption. This study will help the people to maintain their dietary requirements of micronutrients through consumption of tropical fruits. Regular intake of tropical fruits may alleviate the prevalence of micronutrient deficiency problem from Bangladesh and this information will be good resource for the food composition table as well.

\section{Acknowledgements}

The authors are grateful to Majeda Begum, Former Director, IFST, BCSIR, Dhaka for providing laboratory facilities to carry out the research work and also all members of fruit technology research section for helping throughout the research work.

\section{References}

AOAC (2005), Official Methods of Analysis of the Association of Official Analytical Chemists, $18^{\text {th }}$ edition, Verginia, U.S.A.

Carr, A.C. and Frei, B. (1999), Towards a new recommended dietary allowances for vitamin $\mathrm{C}$ based on antioxidant and health effects in humans. Am. J. Clin. Nutr. 69(6): 1086-1107.

Edeoga, H.O. Okwu, D.E. Mbaebie, B.O. (2003), Minerals and nutritive value of some Nigerian medical plants. $J$. of Med. Arom. Plant Sci. 25: 1010-1015.

Gopalan, C. Rama, S.B.V. Balasubra, S.C. (1993), Nutritive Value of Indian Foods, $2^{\text {nd }}$ ed. Indian Council of Medical Research, Hyderabad.

Haque, M.N. Saha, B.K. Karim, M.R. Bhuiyan, M.N.H. (2009), Evaluation of Nutritional and physico-Chemical Properties of Several Selected Fruits in Bangladesh. Bangladesh J. Sci. Ind. Res. 44(3): 353-358.

Jahan, S. Gosh, T. Begum, M. Saha, B.K. (2011), Nutritional Profile of Some Tropical Fruits in Bangladesh: Specially antioxidant vitamins and minerals. Bangladesh J. of Med.Sci. 10(2): 95-113.

Kirk, R. S. and Sawyer, R. (1991), Pearson's composition and analysis of foods. 9th ed. London: Addison-Wesley Longman, Inc. 
Norman, N. (1976), Food Science, $2^{\text {nd }}$ Ed. The Avi publishing company, INC-Westport, Connecticut.

Prakash, D. Upadhyay, G. Gupta, C. Pushpangadan, P. and Singh, K.K. (2012), Antioxidant and free radical scavenging activities of some promising wild edible fruits. Int. Food Res. J. 19(3): 1109-1116.

Rahman, S.A. Rahman, M.F. Codilan, A.L. and Farhana, K.M. (2007), Analysis of the economic benefits from systematic improvements to shifting cultivation and its evolution towards stable continuous agro forestry in the upland of eastern Bangladesh. Int.For.Rev. 9(1): 536-547.

Ranganna, S. (1986), Handbook of Analysis and Quality Control for Fruit and Vegetable Products, Tata McGraw- Hill Publishing Company Ltd. New Delhi. pp. 12-123.
Shui, G. and Leong, L.P. (2006), Residue from star fruit as valuable source for functional food ingredients and antioxidants nutraceuticals. Food Chemistry 97: 277-284.

USDA (2010), National Nutrient Database for Standard Reference, Release 23 (2010).

WHO/ FAO (2002), Expert consultation on human vitamin and mineral requirements, Vitamin C, p. 73, Rome.

Received: 13 January 2013; Revised: 30 January 2014; Accepted: 25 August 2014. 